Meta

Journal des traducteurs

Translators' Journal

\title{
Shakespeare, Teacher of the Hungarian Poets
}

\section{György Radó}

Volume 16, numéro 4, décembre 1971

URI : https://id.erudit.org/iderudit/003904ar

DOI : https://doi.org/10.7202/003904ar

Aller au sommaire du numéro

Éditeur(s)

Les Presses de l'Université de Montréal

ISSN

0026-0452 (imprimé)

1492-1421 (numérique)

Découvrir la revue

Citer cet article

Radó, G. (1971). Shakespeare, Teacher of the Hungarian Poets. Meta, 16(4),

216-221. https://doi.org/10.7202/003904ar d'utilisation que vous pouvez consulter en ligne.

https://apropos.erudit.org/fr/usagers/politique-dutilisation/ 


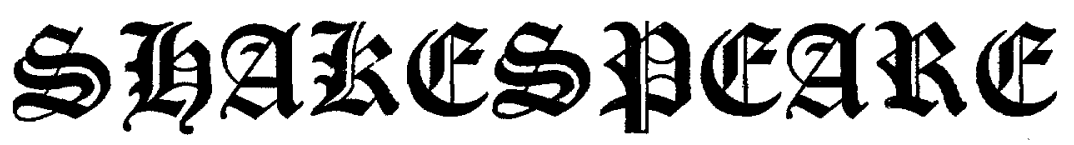

\section{teacher of the}

It is a well-documented fact that Shakespeare, whose cult in Hungary was especially great, stimulated the evolution of the Hungarian national drama and that the first Hungarian actors and stage-managers also learned the laws of their art from the performance of his plays. Let us mention only the book by József Bayer ${ }^{1}$ which presents in 860 pages the documentation only of the first hundred years (1777-1878) of Shakespeare's influence in Hungary.

This fact leads us to a fascinating hypothesis : was it possible that Shakespeare influenced the development of the Hungarian poetic language as well.

Hardly feasible at first glance, perhaps. Could Shakespeare's language contribute to the formation of Hungarian, could the great English poet TEACH the great Hungarian poets the Hungarian language and its poetry? This seems to be improbable, and yet the history of literary translation in Hungary shows that it was so.

Although the isolation of Hungarian literature, for historical reasons, hindered Hungarian readers and spectators in their knowledge of Shakespeare until the end of the xvirth century, when the German and the French translations and performances of his works already had a rich tradition, Hungarian writers quickly made up for lost time. In the second half of the XIXth century the popularity of Shakespeare in Hungary was not behind the great nations of Western Europe and since then his plays have lived in Hungary more vigorously than works by any other classical playwright of world literature. The driving force behind this process were always great Hungarian poets.

Now let us try to show how their efforts, namely their translations of Shakespeare's works, influenced the formation of their own poetry, style and language.

1. József Bayer, Shakespeare drámái hazánkban (The Dramas of Shakespeare in our Country), Budapest, 1909, vol. I-II. 
We shall show when and under what circumstances their translations of Shakespeare's works appeared and the definite change in their own poetic works afterwards.

Hungary, which had a flourishing culture in the Middle Ages, was divided into three parts under Turkish rule and lay dormant until the end of the xvirth century when its own cultural life awoke again. In the history of Hungary this age is called «the age of Hungarian enlightenment and its outstanding figure is Ferenc Kazinczy ${ }^{2}$ (1759-1831). The first influences of Shakespeare's works in Hungary are due to his excellent poet : his Hamlet, the first work by Shakespeare translated into Hungarian, was published in 1790. Although this text was not made from the original, but from its imperfect German prose adaptation, nevertheless Shakespeare's genius influenced Kazinczy in a dynamic manner. This great Hungarian poet, who started the renewal of his national language, wrote in the preface to his translation that the first Hungarian actress to play Ophelia would provide an example of Hungarian patriotism, while the interpreter of Hamlet could give an idea of the beauties of the Hungarian language. He analyses the process by which a dramatic masterpiece makes good actors great, and he concludes that Hamlet is the best play for this purpose. Another fact, which proves how important this translation was in Kazinczy's poetic career : as a poet and as a poet-translator his Muse had been sentimentalism which was so fashionable in his time, but the translation of Hamlet was the turning-point in his sensitivity, and was responsible for his subsequent activity as a language reformer. Kazinczy's translation of Shakespeare's drama made him the most respected shaper of the new Hungarian literary language and style.

In the first half of the xIxth century Hungarian audiences got acquainted with several plays by Shakespeare, but these translations were not worthy of the original even though the Hungarian Academy of Sciences had offered a prize for the best translation of Shakespeare's works. In 1848, however, at a landmark in Hungary's history, when the European liberation movement brought the fight for constitutional freedom and independence to Hungary too, then a most important step was taken for the reception of Shakespeare in Hungary : the three greatest classic representatives of Hungarian poetry, Mihaly Vörösmarty, Sándor Petöfi and János Arany undertook the translation of all the plays of Shakespeare. In that period, during the great cataclysm of the Hungarian War of Independence, when Petöfi lost his life, this translation project could be carried out in part only. The translations made by Vörösmarty, Petöfi and Arany still belong to the thesaurus of Shakespeare's works in Hungarian, and here is the point we are trying to make, they were a very important phase in the poetic evolution of these writers.

Mihaly Vörösmarty (1800-1855) the outstanding figure of Hungarian national romanticism, who revived ancient times in his heroic poems, dramas, elegies and romances, the author of intimate sentimental and philosophical lyrics, translated Julius Caesar. He was twenty years old when he first became acquainted with Shakespeare's works, and his enthusiasm for the great Elizabethan poet never flagged. Then, in 1840, at the summit of his career, he began to translate

2. Ferenc Kazinczy, Kül-Földi Játszó-Színje (Foreign Theatre by Ferenc Kazinczy), Kassa, 1790, vol. I. See : Bayer, op. cit., vol. I, p. 136. 
his teacher; it was as if his former works had been mere stepping stones to his brilliant translation of Julius Caesar. Hungarian essayists have analytically demonstrated how the art of Shakespeare influenced certain works of Vörösmarty; let us mention only some interesting examples. In his comedy, The Secrets of the Veil, there are some elements of Much Ado about Nothing and of Love's Labours Lost, but as the literary historian Elemér Császár pointed out Vörösmarty treated this material freely as great poets do - in the same way as Shakespeare himself with his own source material ${ }^{3}$. Furthermore, the same Elemér Császár demonstrates that Vörösmarty, when writing his fairy play Csongor and Tünde, a most poetic Hungarian drama, did not take concrete elements from Shakespeare, but was indebted to him for his poetic impulse. Shakespeare transformed old tales into romantic dramas; Vörösmarty did the same with an old Hungarian tale and some of his methods he learned also from Shakespeare : one of his characters, Balga, has touches of Puck and Bottom ; indeed, the very style of this play shows the influence of $A$ Midsummer Night's Dream ${ }^{4}$. After reaching the summit of his career Vörösmarty turned towards political interests and in his later lifetime, while witnessing the tragic end of the Hungarian War of Independence created new masterpieces only seldom. His second translation, King Lear, is markedly inferior to his translation of Julius Caesar.

The name of the greatest Hungarian poet, Sándor Petöfi (1823-1849) is connected with Shakespeare's name by his translation of Coriolanus. Petöfi wrote in 1847 : "Shakespeare is himself half of the Creation» and one year later he translated Shakespeare, doubtless at the zenith of his life. He made a list of Shakespeare's dramas (about half of Shakespeare's total output), which he wanted to translate. Why did he choose Coriolanus as the first?

Lajos Hatvany, a Hungarian historian of literature who was expelled from his country between the two wars and who then compiled the chronicle of Petöfi's life mostly in the library of the British Museum, answered this question ${ }^{5}$ when he states that Petöfi « recognized the patrician counterpart of his own plebeian pride ${ }^{6} \gg$ in the figure of Coriolanus. As a result, says Hatvany, "Coriolanus defies the whole world with the same fierceness and obstinacy in the Hungarian text of the play as he does in the original English ${ }^{7} \gg$. This identification of the translator with the author actually influenced not only the works of Petöfi written in the next eventful months, but also his whole behaviour : his Roman-like patriotism as well as his outrage when he, the poet of liberty, was defeated at the polls. The further plans of Petöfi concerning the translation of Shakespeare's works were cut short by the conflict of historical events with his own ambition as a dramatist.

János Arany (1817-1882) inclined rather to epic poetry and was especially destined for literary translation by his erudition in world literature. He translated three plays by Shakespeare. Two of them, Hamlet and A Midsummer Night's

\footnotetext{
3. Elemér Császár, Shakespeare és a magyar költészet (Shakespeare and Hungarian Poetry), Budapest, 1917, p. 65.

4. Császár, op. cit., p. 158-161.

5. Lajos Hatvany, Igy élt Petöfi (That is How Petöfi Lived), Budapest, 1955-1957, vol. I-V.

6. Hatvany, op. cit., vol. IV, p. 186.

7. Hatvany, op. cit., vol. IV, p. 186.
} 
Dream have been played often since then in Hungarian theaters and the text of Arany's translation became as indispensable an attribute of Hungarian literature as his best original works.

Arany translated Shakespeare in the sixties, and after the two plays mentioned above he finished the Hungarian version of The Life and Death of King John in 1867. Formerly, when he had planned the translation of the complete Shakespeare together with Petöfi and Vörösmarty, Arany was still searching for the epic genre suitable to him; he found it in the fifties, just when he began to concern himself intensively with Shakespeare. His usual literary genre was the ballad, and indeed he was the greatest writer of ballads in Hungarian literature ; curiously enough, he proved to be Shakespeare's disciple in this non-Shakespearean genre. The ballad was not one of Shakespeare's literary genres, althoug it is near to him : actually the analysis of similar elements in Shakespeare's and Arany's works led several Hungarian literary critics to the comparison of tragedy and ballad. Pál Gyulai still refers to Arany as «the Shakespeare of the ballad » in his necrology ${ }^{8}$, but Frigyes Riedl demonstrates in detail in his book on Arany ${ }^{9}$ what the similar and dissimilar traits are with respect to these two poets and their literary genres : his detailed analysis begins with a statement : «Arany is the poet of conscience, and thus he comes naturally to the description of madness in his ballads. He writes about the awareness of guilt and the qualms of conscience drive the wrongdoer mad in both Arany and in Shakespeare. In his description of madness Arany is obviously under the influence of Shakespeare. Shakespearean art strives to bring the various phenomena of madness into full relationship with the complicated and tragic denouement of the drama, while Arany was able to apply the same phenomena to the construction of the ballad, to its grave and roughly sketched narration ${ }^{10}$. $》$ That is why János Arany can be considered the best Hungarian pupil of Shakespeare, even if there are others who have absorbed more elements from him, because Arany employed his experiences of studying and translating Shakespeare in his own works in a creative, reproductive way.

Unfortunately the plan of the «big three » to enrich the literature of their country with the translation of all the works by William Shakespeare failed : they finished the translation of six plays only. Adding the works of other fine and conscientious interpreters to those six masterpieces of translation, the first Hungarian edition of the complete works of Shakespeare was published from 1868 to 1878 .

It is not our aim to follow the history of the Hungarian translations, performances and publications of Shakespeare's works or that of Hungarian critical literature about him. This could be recounted only in several massive volumes. We mention only that a yearbook called Hungarian Shakespeare Collection was published from 1908 to 1917 , each volume of which contained about 300 pages. A mere bibliography of the Hungarian essays on Shakespeare published in this yearbook or elsewhere would be a bulky volume.

8. Pál Cyulai, Arany János. Emlékbeszéd (János Arany. A Necrology), Budapest, 1891.

9. Frigyes Riedl, Arany János (János A rany), 4th ed., Budapest, 1920.

10. Riedl, op. cit., p. 164-165. 
As the literary plans of Vörösmarty, Petöfi and Arany remained incomplete, the translation of Shakespeare's works was henceforth an open and attractive task for Hungarian poets.

In 1916, the 300th anniversary of Shakespeare's death, Mihály Babits (1883-1941), an excellent poet-philosopher and a master of classical and modern forms, translated The Tempest. Certainly his work on this translation together with the tragic experience of World War I rescued Babits from his former attitude : isolation from the outside world. On the contrary, he now expressed - still in his own manner - certain social experiences in his writings.

Similar to Babits in his ideas and attitude, but more gentle and more impressionable was Dezsö Kosztolányi (1885-1936). He translated three plays of Shakespeare : Romeo and Juliet, King Lear and The Winter's Tale. Kosztolányi himself tells us what his own poetic work gained from the translation : "We polished our language by means of foreign poems, wanting to obtain a rich and easy, a substantial and noble idiom for the expression of our own complicated feelings... In my opinion, literary translation is creation and not reproduction. The artist is connected with the poem, which takes its new form from him, as with his own life, the rebulous quality of which becomes fixed in his poems... My translations do not relate to the original as a picture's reproduction to a specific picture but as a picture to the object represented by it ${ }^{11}$. Although Kosztolányi wrote these lines in a preface to his book of translations of contemporary poetry, nevertheless there cannot be any doubt that the upholder of those principles acquired « a rich and easy, a substantial and noble idiom» for the expression of his own complicated feelings from the translation of Shakespeare's plays as well. So Kosztolányi sought and found something similar in Shakespeare for himself, just as Kazinczy had done fourteen decades before.

Lörinc Szabó (1900-1957) called his second cycle of poems Caliban, choosing a line by Shakespeare for his motto : «Caliban... burn but his books. » And he identifies himself with «the savage and deformed Slave» of The Tempest not only in the title and in the motto of his work : his very character, the anarchistic unruliness of his youth was modelled on this strangely « deformed 》 Shakespearean figure, as Szabó himself avowed. «Burn the books, Caliban, hammer me into iron, beat me into immense constructions, my intestines into steel ${ }^{12} 》-$ such was the desire of the poet for himself and for those who had similar wishes and thoughts.

This poet later translated five plays by Shakespeare : Macbeth, Timon of Athens, Troilus and Cressida, As You Like It and Twelfth Night as well as all his sonnets. A well-known contemporary poet, Gyula Illyés wrote about him : «His greatest teacher, from whom he learned to treat ideas like persons, to address them in a personal form, to personify abstract conceptions, was the immortal teacher of all poets : Shakespeare. Lörinc Szabó has written poems which have an independent existence like a soliloquy from one of Shakespeare's dramas ${ }^{13}$.» 11. Dezsö Kosztolanyi, Modern Költok (Modern Poets), 2nd ed., Budapest, 1921, vol. I,

12. Lörinc Szabó, Válogatot versei (Selected Poems), Budapest, 1956, p. 64.

13. Guyla Illyés, Preface, in Szabó, op. cit., p. 29. 
In the past two decades collections of all the works by William Shakespeare translated into Hungarian were published several times. These series began in 1948 with the publication of all his dramatic works, containing classical translations as well as new, modern ones in four volumes. The same collection refurbished with other translations appeared in six volumes in 1955 and was completed with a volume containing all poems by Shakespeare in 1962 . Since then, this collection has been reprinted. The register of the translators contains, besides the names of classical Hungarian poets and those of the young generation, some well-known representatives of Hungarian literature today as well, such as Gábor Devecseri, translator also of all the works by Homer and of other Greek and Roman classics, the poets Lajos Áprily, József Fodor, György Rónay, György Somloyó, István Vas and Sándor Weöres as well as famous novelist and playwright László Németh. Analysing their style, one will find that their work, to a great extent, has been influenced by their fascination for Shakespeare.

This is a living process : it began in 1790 with the first Hungarian translation of a play by Shakespeare and still continues today with new translations.

To sum up : we have seen how Shakespeare has influenced the evolution of literary style and expression of the Hungarian poetic language. At the dawn of the renewal of the Hungarian language, Ferenc Kazinczy expected to obtain «the beauties of the Hungarian language » from the actor playing Hamlet ; Mihály Vörösmarty, as the author of a fairy play, formed his mode of expression by using $\boldsymbol{A}$ Midsummer Night's Dream as a model. His former works were only preparations for the great achievement of the translation of Julius Caesar ; Sándor Petofi could identify himself with the character of Shakespeare's Coriolanus; János Arany learned the technique of another genre, the ballad, from studying Shakespeare's dramatic craft ; Mihály Babits drew inspiration from The Tempest in forming his own human attitude; Dezsö Kosztolányi found an idiom for the expression of his own feelings from the translation of Shakespeare's plays ; Lörinc Szabo, the poet-Caliban, learned the art of the personification of ideas in a way that is typical of Shakespeare; the continuation of this variegated, rich tradition is carried on today by Hungarian translators of Shakespeare.

What first looked improbable, proves to be true. Shakespeare's English contributed to the formation of a fine poetic mode in the Hungarian language. The great English dramatist teaches Hungarian poets style, ways of expression and individual art.

GYöRGY RADó *

* Texte revu et corrigé par Daniel Slote. 